\title{
Draft genome sequences of three Xanthomonas translucens pathovar reference strains (pv. arrhenatheri, pv. poae and pv. phlei) with different specificities for forage grasses
}

\author{
Lena Hersemann ${ }^{1}$, Daniel Wibberg ${ }^{2}$, Franco Widmer ${ }^{1}$, Frank-Jörg Vorhölter ${ }^{2}$ and Roland Kölliker ${ }^{1 *}$ (D)
}

\begin{abstract}
As causal agents of bacterial wilt in pastures and meadows, bacteria of the species Xanthomonas translucens are a serious issue in forage grass production. So far, only little is known about host-pathogen interactions at the molecular level and the lack of comprehensive genome data impeded targeted breeding strategies towards resistant forage grass cultivars. Here we announce the draft genome sequences of three grass-pathogenic Xanthomonas translucens pathotype strains, i.e. pv. arrhenatheri LMG 727, pv. poae LMG 728 and pv. phlei LMG 730 isolated from Arrhenatherum elatius (L.) P. Beauv. ex J. Presl \& C. Presl (Switzerland), Poa trivialis L. (Switzerland) and Phleum pratense L. (Norway), respectively. The genomes of all three strains revealed a non-canonical type III secretion system and a set of 22 type III effectors as common virulence-related traits. Distinct inter-pathovar differences were observed for the lipopolysaccharide biosynthesis gene cluster and the presence of nonribosomal peptide synthetases.
\end{abstract}

Keywords: Plant pathogen, Bacterial wilt, hrp genes, Effector genes, LPS gene cluster, NRPS

Abbreviations: CDS, Coding sequence; CTAB, Cetyltrimethylammonium bromide; LPS, Lipopolysaccharide; NRPS, Non-ribosomal peptide synthetase; PIP, Plant-inducible promoter; T1SS, Type I secretion system; T2SS, Type II secretion system; T3Es, Type III effector proteins; TALEs, Transcription activator-like effectors

\section{Introduction}

Xanthomonas spp. are known as destructive plant pathogens affecting a variety of important crop plants [1]. In forage grass production, bacterial wilt caused by pathovars of the species Xanthomonas translucens is considered to be one of the most important diseases in temperate grassland regions [2]. Characteristic symptoms include withering of leaves and tillers due to pathogen colonization of the vascular system $[3,4]$. In addition, chlorotic and later also necrotic lesions can be observed along infected leaves. Affected grass species

\footnotetext{
* Correspondence: roland.koelliker@agroscope.admin.ch

${ }^{1}$ Molecular Ecology, Institute for Sustainability Sciences, Agroscope, Zurich,

Switzerland

Full list of author information is available at the end of the article
}

belong to a variety of different genera including Lolium L., Festuca L., Phleum L., Poa L. and Arrhenatherum P. Beauv. [2-4]. In the first years after the initial description of bacterial wilt of forage grasses in 1975 in Switzerland [3], pathogens isolated from infected plants were uniformly assigned to Xanthomonas campestris pv. graminis [5, 6], later reclassified to Xanthomonas translucens pv. graminis [7]. However, comprehensive studies on host range specificities pointed towards a further differentiation into four different Xanthomonas translucens pathovars named pv. graminis, pv. arrhenatheri, pv. poae and pv. phlei [4]. While the pathovar graminis is characterized by a broad host range including grass species of different genera, the other three $X$. translucens pathovars show distinct host adaptation to the plant species they 
have been isolated from: A. elatius (X. translucens pv. arrhenatheri LMG 727), P. trivialis (X. translucens pv. poae LMG 728) and P. pratense (X. translucens pv. phlei LMG 730) [4].

The genome data of these host-specialized pathovar reference strains will allow insight into distinct virulence factors involved in host-specific adaption at the molecular level. In combination with the recently sequenced $X$. translucens pv. graminis strain Xtg29 [8], these data will valuably complement the genome information on $X$. translucens pathovars which are causing bacterial wilt on forage grasses.

\section{Organism information}

\section{Classification and features}

Xanthomonas spp. are Gram-negative, rod-shaped bacteria, characterized by their typical yellow appearance with varying tones from pale to deep yellow, caused by the pigment xanthomonadin (Fig. 1) [9]. Optimal growth conditions include a temperature of $28{ }^{\circ} \mathrm{C}$ and a $\mathrm{pH}$ value between 5.5 and 6.5 [10]. For the cultivation of $X$. translucens pathovars, isolated from stalks of infected grasses, GYCA medium containing glucose, yeast extract, $\mathrm{CaCO}_{3}$ and agar represents a suitable medium [11, 12]. Further common characteristics of the three pathovar reference strains LMG 727, LMG 728 and LMG 730 are summarized in Table 1.

Figure 2 shows the phylogenetic position of the three forage grass affecting Xanthomonas translucens pathovar reference strains based on a partial gyrB DNA sequence of $530 \mathrm{bp}[13,14]$. For comparison, the type strain NCPPB 3002 of the rice-affecting species Xanthomonas oryzae was used.

\section{Genome sequencing information Genome project history}

The strains LMG 727, LMG 728 and LMG 730 were selected for sequencing based on their distinct differences in host range specificities on forage grasses. The whole-genome shotgun projects have been deposited in DDBJ/EMBL/GenBank under the accession numbers CXOI01000001-CXOI01000089 (LMG 727), CXОК01000001-CXОК01000190 (LMG 728) and CXOJ01000001-CXOJ01000142 (LMG 730). Table 2 presents the project information and its association with MIGS version 2.0 compliance [15].

\section{Growth conditions and genomic DNA preparation}

All three strains were obtained from the BCCM/LMG culture collection of the Laboratory of Microbiology, Ghent University in Belgium (accession numbers: LMG 727, LMG 728 and LMG 730). The strains were grown for $15-20 \mathrm{~h}$ in CircleGrow broth (MP Biomedicals, Santa Ana, USA) at $28{ }^{\circ} \mathrm{C}$ and $200 \mathrm{rpm}$. Genomic DNA was extracted following the protocol for isolation of bacterial genomic DNA using CTAB [16] without the lysozyme application and the subsequent incubation step at $37{ }^{\circ} \mathrm{C}$. The quality of genomic DNA was assessed by gel-electrophoresis and the quantity was estimated by a fluorescence-based method using the Quant-iT PicoGreen dsDNA kit (Invitrogen, Carlsbad, USA) and the Tecan Infinite 200 Microplate Reader (Tecan Deutschland GmbH, Crailsheim, Germany).

\section{Genome sequencing and assembly}

A total of $4 \mu \mathrm{g}$ genomic DNA of each isolate was used to construct a paired-end sequencing library (TruSeq DNA LT Sample Prep Kit, Illumina Inc., San Diego, USA), which was sequenced applying the paired-end protocol on an Illumina MiSeq system. Upon sequencing and processing of the raw data, a de novo assembly was performed using the GS De Novo Assembler software version 2.8. with default settings. The de novo assemblies yielded 58 scaffolds (89 contigs) for LMG 727, 129 scaffolds (190 contigs) for LMG 728 and 84 scaffolds (142 contigs) for LMG 730, respectively.

\section{Genome annotation}

Initially, automatic gene prediction and annotation were performed using the genome annotation system GenDB 2.0 [17] and the gene identification strategy

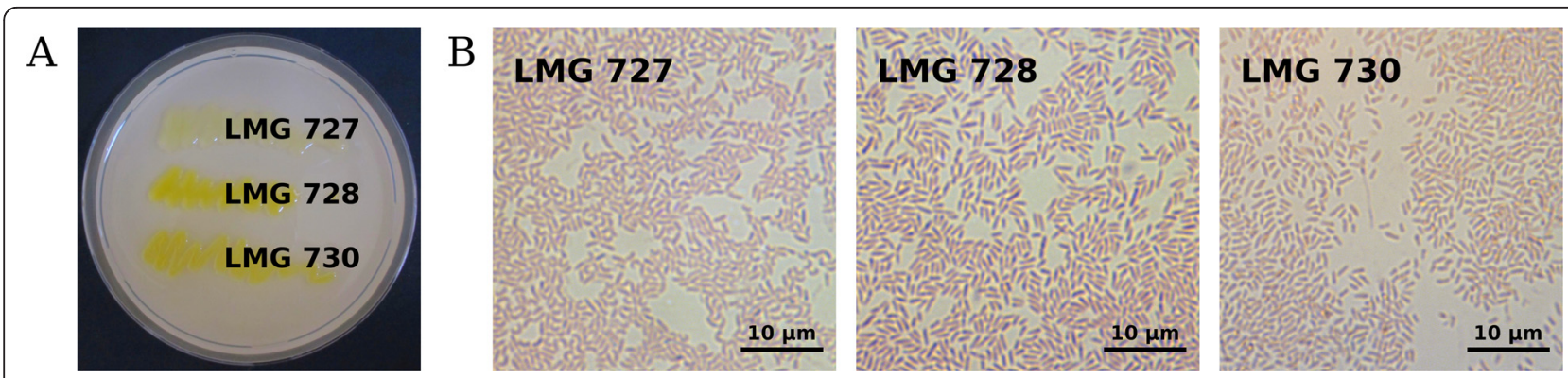

Fig. 1 X. translucens pv. arrhenatheri LMG 727, X. translucens pv. poae LMG 728 and X. translucens pv. phlei LMG 730 grown on GYCA medium (a) and visualized by light microscopy after over-night cultivation, heat fixation and fuchsine staining (b) 
Table 1 Classification and general features of $X$. translucens pv. arrhenatheri LMG 727, X. translucens pv. poae LMG 728 and X. translucens pv. phlei LMG 730 according to MIGS recommendations [15]

\begin{tabular}{|c|c|c|c|}
\hline MIGS ID & Property & Term & Evidence code $^{a}$ \\
\hline & Classification & Domain Bacteria & TAS [53] \\
\hline & & Phylum Proteobacteria & TAS [54] \\
\hline & & Class Gammaproteobacteria & TAS $[55,56]$ \\
\hline & & Order Xanthomonadales & $\operatorname{TAS}[56,57]$ \\
\hline & & Family Xanthomonadaceae & $\operatorname{TAS}[56,58]$ \\
\hline & & Genus Xanthomonas & $\operatorname{TAS}[59,60]$ \\
\hline & & Species Xanthomonas translucens & TAS [7] \\
\hline & & Pathovar arrhenatheri Strain: LMG 727 & TAS [61] \\
\hline & & Pathovar poae Strain: LMG 728 & TAS [61] \\
\hline & & Pathovar phlei Strain: LMG730 & TAS [61] \\
\hline & Gram stain & Negative & $\operatorname{TAS}[9,10]$ \\
\hline & Cell shape & Rod-shaped & TAS [9] \\
\hline & Motility & Motile & IDA \\
\hline & Sporulation & Non-sporulating & TAS [9] \\
\hline & Temperature range & $10-35^{\circ} \mathrm{C}$ & NAS \\
\hline & Optimum temperature & $28^{\circ} \mathrm{C}$ & TAS [9] \\
\hline & pH range; Optimum & $5.5-6.5$ & $\operatorname{TAS}[9,10]$ \\
\hline & Carbon source & $\begin{array}{l}\text { D-glucose, D-mannose, sucrose, trehalose, } \\
\text { cellobiose, D-fructose }\end{array}$ & TAS [10] \\
\hline MIGS-6 & Habitat & Plant-associated & TAS [4] \\
\hline MIGS-6.3 & Salinity & Tolerance to $1-2 \% \mathrm{NaCl}$ & TAS [10] \\
\hline MIGS-22 & Oxygen requirement & Aerobic & $\operatorname{TAS}[9,10]$ \\
\hline MIGS-15 & Biotic relationship & Parasitic & TAS [4] \\
\hline MIGS-14 & Pathogenicity & Pathogenic & TAS [4] \\
\hline \multirow[t]{3}{*}{ MIGS-4 } & Geographic location & LMG 727: Switzerland & TAS [10] \\
\hline & & LMG 728: Switzerland & TAS [10] \\
\hline & & LMG 730: Norway & TAS [10] \\
\hline \multirow[t]{3}{*}{ MIGS-5 } & Sample collection & LMG 727: 1978 & TAS [10] \\
\hline & & LMG 728: 1978 & TAS [10] \\
\hline & & LMG 730: 1978 & TAS [10] \\
\hline MIGS-4.1 & Latitude & Not reported & \\
\hline MIGS-4.2 & Longitude & Not reported & \\
\hline MIGS-4.4 & Altitude & Not reported & \\
\hline
\end{tabular}

${ }^{a}$ Evidence codes - IDA inferred from direct assay, TAS traceable author statement (i.e., a direct report exists in the literature), NAS non-traceable author statement (i.e., not directly observed for the living, isolated sample, but based on a generally accepted property for the species, or anecdotal evidence). These evidence codes are from the Gene Ontology project [62]

Prodigal [18]. Putative rRNA and tRNA genes were identified with RNAmmer [19] and tRNAscan-SE [20]. An automatic annotation was computed based on results of the following different tools: similarity searches were performed against different databases including SWISS-PROT [21], KEGG [22], Pfam [23], TIGRFAM [24] and InterPro [25]. Additionally, SignalP [26] and TMHMM [27] were applied. Finally, the coding sequences were functionally classified by assigning a Cluster of Orthologous Groups number and its corresponding COG category [28] and Gene Ontology numbers [29]. CRISPR repeats were examined using the CRISPR recognition tool [30].

\section{Genome properties}

Whole genome sequencing of the strains LMG 727, LMG 728 and LMG 730 resulted in 109, 249 and 315 fold coverage. Annotation of the 4.76, 4.61 and $4.40 \mathrm{Mb}$ genomes 


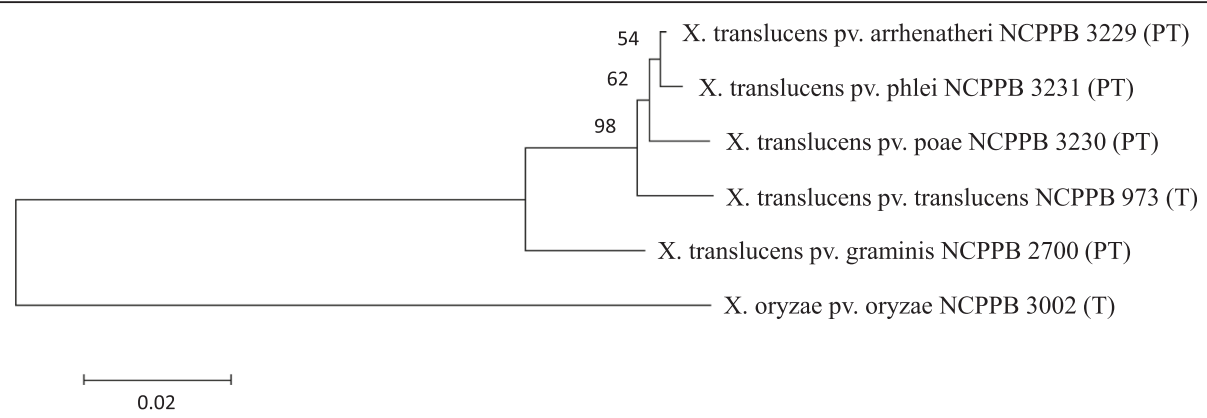

Fig. 2 Phylogenetic tree based on partial gyrB sequences using the neighbor-joining method with 1,000 bootstrap resampling and calculated with MEGA version 6 [63]. The analysis included type strains (T) and pathotype strains (PT) of the genus Xanthomonas listed with their culture collection numbers

featuring a GC content of 68.31 to $68.37 \%$ was performed within the GenDB 2.0 system and resulted in the prediction of 3,878, 3,851 and 3,749 coding sequences, as well as the following numbers of RNA genes: 55 (3 rRNA genes and 52 tRNA genes), 55 (4 rRNA genes and 51 tRNA genes) and 54 ( 3 rRNA genes and 51 tRNA genes) for the strains LMG 727, LMG 728 and LMG 730. A total of 15 additional genome features were recorded (Table 3) and the distribution of genes into COG functional categories is presented in Table 4 .

Table 2 Project information

\begin{tabular}{|c|c|c|c|c|}
\hline MIGS ID & Property & LMG 727 & LMG 728 & LMG 730 \\
\hline MIGS 31 & $\begin{array}{l}\text { Finishing } \\
\text { quality }\end{array}$ & $\begin{array}{l}\text { High quality } \\
\text { draft }\end{array}$ & $\begin{array}{l}\text { High quality } \\
\text { draft }\end{array}$ & $\begin{array}{l}\text { High quality } \\
\text { draft }\end{array}$ \\
\hline MIGS-28 & $\begin{array}{l}\text { Libraries } \\
\text { used }\end{array}$ & $\begin{array}{l}\text { One Paired- } \\
\text { end }\end{array}$ & $\begin{array}{l}\text { One Paired- } \\
\text { end }\end{array}$ & $\begin{array}{l}\text { One Paired- } \\
\text { end }\end{array}$ \\
\hline MIGS 29 & $\begin{array}{l}\text { Sequencing } \\
\text { platforms }\end{array}$ & Illumina MiSeq & Illumina MiSeq & Illumina MiSeq \\
\hline $\begin{array}{l}\text { MIGS } \\
31.2\end{array}$ & $\begin{array}{l}\text { Fold } \\
\text { coverage }\end{array}$ & $109 x$ & $249 x$ & $315 x$ \\
\hline MIGS 30 & Assemblers & Newbler 2.8 & Newbler 2.8 & Newbler 2.8 \\
\hline \multirow[t]{6}{*}{ MIGS 32} & $\begin{array}{l}\text { Gene calling } \\
\text { method }\end{array}$ & Prodigal & Prodigal & Prodigal \\
\hline & Locus Tag & XTALMG727 & XTPLMG728 & XTPLMG730 \\
\hline & Genbank ID & CXOI00000000 & CXOK00000000 & CXOJ00000000 \\
\hline & $\begin{array}{l}\text { GenBank } \\
\text { Date of } \\
\text { Release }\end{array}$ & 2015/08/14 & 2015/08/14 & 2015/08/14 \\
\hline & GOLD ID & Gs0118809 & Gs0118809 & Gs0118809 \\
\hline & BIOPROJECT & PRJEB9902 & PRJEB9904 & PRJEB9905 \\
\hline \multirow[t]{2}{*}{ MIGS 13} & $\begin{array}{l}\text { Source } \\
\text { Material } \\
\text { Identifier }\end{array}$ & LMG727 & LMG728 & LMG730 \\
\hline & $\begin{array}{l}\text { Project } \\
\text { relevance }\end{array}$ & $\begin{array}{l}\text { Study of } \\
\text { grassland } \\
\text { pathogens }\end{array}$ & & \\
\hline
\end{tabular}

\section{Extended insights}

\section{Analysis of the type III effector repertoire}

Type III effector proteins (T3Es) represent important virulence factors which facilitate successful host colonization by interfering with plant defense mechanisms [31]. Vice versa, effector proteins are able to trigger defense responses if recognized by corresponding resistance genes within the plant [32]. Thus, effector proteins are considered as important candidate genes, contributing to host range specificity [33]. In order to identify T3Es within the genome data of the three $X$. translucens pathotype strains LMG 727, LMG 728 and LMG 730, their corresponding CDS were compared against publicly available effector protein sequences [34]. An e-value of $1 \mathrm{E}-15$ was used as a threshold for identifying putative T3Es. Additionally, the presence of plantinducible promoter boxes has been identified as described recently [8]. Genes with upstream PIP-boxes were analyzed by applying Blastx against the nonredundant protein sequences (nr) database [35]. Table 5 represents a list of putative type III effector proteins and corresponding Xanthomonas effector classes [36] identified for LMG 727, LMG 728 and LMG 730. Listed percentage identities and e-values refer to the lowest values obtained in Blastp analysis within the homologous CDS of the three pathovar reference strains. Analysis of the effector repertoire revealed the presence of 30,31 and 29 putative T3Es in the genome data of LMG 727, LMG 728 and LMG 730, respectively. Twenty-two putative effector proteins were conserved among all three pathotype strains and 21 of those could clearly be assigned to one of the known effector classes of the genus Xanthomonas. Furthermore, one, three and five homologues of transcription activator like effectors (TALEs) [37] have been identified for LMG 730, LMG 727 and LMG 728, respectively, and may be worth deeper analysis.

The secretion of T3Es is mediated by the type III secretion system [38]. All three sequenced strains (LMG 
Table 3 Genome statistics

\begin{tabular}{|c|c|c|c|c|c|c|}
\hline Attribute & LMG 727 & $\%$ & LMG 728 & $\%$ & LMG 730 & $\%$ \\
\hline Genome size (bp) & $4,754,971$ & 100.00 & $4,610,480$ & 100.00 & $4,399,523$ & 100.00 \\
\hline DNA coding (bp) & $4,132,338$ & 86.90 & $3,961,227$ & 85.91 & $3,805,731$ & 86.50 \\
\hline DNA G+C (bp) & $3,250,022$ & 68.35 & $3,149,419$ & 68.31 & $3,007,954$ & 68.37 \\
\hline DNA scaffolds & 58 & 100.00 & 129 & 100.00 & 84 & 100.00 \\
\hline Total genes & 3,933 & 100.00 & 3,906 & 100.00 & 3,803 & 100.00 \\
\hline Protein coding genes & 3,878 & 98.6 & 3,851 & 98.6 & 3,749 & 98.6 \\
\hline RNA genes & 55 & 1.40 & 55 & 1.40 & 54 & 1.40 \\
\hline Pseudo genes & 0.00 & 0.00 & 0.00 & 0.00 & 0.00 & 0.00 \\
\hline Genes in internal clusters & 978 & 24.86 & 924 & 23.65 & 876 & 23.03 \\
\hline Genes with function prediction & 2,781 & 70.7 & 2,759 & 70.63 & 2,697 & 70.91 \\
\hline Genes assigned to COGs & 2,987 & 75.94 & 2,935 & 75.14 & 2,928 & 76.99 \\
\hline Genes with Pfam domains & 3,045 & 77.42 & 2,984 & 76.39 & 2,968 & 78.04 \\
\hline Genes with signal peptides & 585 & 14.87 & 586 & 15 & 553 & 14.54 \\
\hline Genes with transmembrane helices & 954 & 24.25 & 935 & 23.93 & 918 & 24.13 \\
\hline CRISPR repeats & 0.00 & 0.00 & 0.00 & 0.00 & 0.00 & 0.00 \\
\hline
\end{tabular}

Table 4 Number of genes associated with general COG functional categories

\begin{tabular}{|c|c|c|c|c|c|c|c|}
\hline Code & LMG 727 & $\%$ & LMG 728 & $\%$ & LMG 730 & $\%$ & Description \\
\hline J & 173 & 4.46 & 173 & 4.49 & 171 & 4.56 & Translation, ribosomal structure and biogenesis \\
\hline A & 2 & 0.00 & 2 & 0.00 & 3 & 0.00 & RNA processing and modification \\
\hline K & 219 & 5.56 & 205 & 5.32 & 204 & 5.44 & Transcription \\
\hline L & 136 & 3.5 & 136 & 3.53 & 135 & 3.60 & Replication, recombination and repair \\
\hline B & 1 & 0.00 & 1 & 0.00 & 1 & 0.00 & Chromatin structure and dynamics \\
\hline D & 33 & 0.85 & 32 & 0.83 & 33 & 0.88 & Cell cycle control, Cell division, chromosome partitioning \\
\hline V & 71 & 1.83 & 62 & 1.6 & 70 & 1.86 & Defense mechanisms \\
\hline $\mathrm{T}$ & 286 & 7.37 & 269 & 6.98 & 279 & 7.44 & Signal transduction mechanisms \\
\hline M & 240 & 6.18 & 239 & 6.2 & 231 & 6.16 & Cell wall/membrane biogenesis \\
\hline N & 124 & 3.19 & 126 & 3.27 & 122 & 3.25 & Cell motility \\
\hline U & 123 & 3.17 & 116 & 3.01 & 123 & 3.28 & Intracellular trafficking and secretion \\
\hline $\mathrm{O}$ & 0.00 & 0.00 & 0.00 & 0.00 & 0.00 & 0.00 & Posttranslational modification, protein turnover, chaperones \\
\hline C & 195 & 5.02 & 195 & 5.06 & 191 & 5.09 & Energy production and conversion \\
\hline G & 211 & 5.44 & 214 & 5.55 & 209 & 5.57 & Carbohydrate transport and metabolism \\
\hline $\mathrm{E}$ & 248 & 6.39 & 244 & 6.33 & 249 & 6.64 & Amino acid transport and metabolism \\
\hline $\mathrm{F}$ & 75 & 1.93 & 76 & 1.97 & 72 & 1.92 & Nucleotide transport and metabolism \\
\hline $\mathrm{H}$ & 147 & 3.79 & 141 & 3.66 & 143 & 3.81 & Coenzyme transport and metabolism \\
\hline । & 141 & 3.63 & 134 & 3.47 & 135 & 3.60 & Lipid transport and metabolism \\
\hline P & 196 & 5.05 & 198 & 5.14 & 189 & 5.04 & Inorganic ion transport and metabolism \\
\hline Q & 147 & 3.79 & 76 & 1.97 & 75 & 2.00 & Secondary metabolites biosynthesis, transport and catabolism \\
\hline $\mathrm{R}$ & 369 & 9.51 & 364 & 9.45 & 356 & 9.49 & General function prediction only \\
\hline S & 315 & 8.12 & 316 & 8.2 & 319 & 8.50 & Function unknown \\
\hline- & 891 & 22.97 & 916 & 23.78 & 821 & 21.89 & Not in COGs \\
\hline
\end{tabular}


Table 5 Homologues of type III effector proteins

\begin{tabular}{|c|c|c|c|c|c|}
\hline Effector class $^{\mathrm{a}}$ & LMG $727^{\mathrm{b}}$ & LMG $728^{b}$ & LMG $730^{\mathrm{b}}$ & Identity (\%) & E-value \\
\hline \multirow[t]{2}{*}{ AvrBs2 } & XTALMG727_3766 & XTPLMG728_3304 & XTPLMG730_3385 & 92.04 & 0.0 \\
\hline & XTALMG727_3767 & XTPLMG728_3305 & XTPLMG730_3384 & 89.37 & 0.0 \\
\hline \multirow[t]{5}{*}{ XopAA } & XTALMG727_0004* & XTPLMG728_1109* & XTPLMG730_1729 & 79.86 & 0.0 \\
\hline & $N$ & XTPLMG728_0423 & $N$ & & \\
\hline & N & XTPLMG728_0424 & $N$ & & \\
\hline & $\mathrm{N}$ & XTPLMG728_0425 & $N$ & & \\
\hline & $N$ & XTPLMG728_0426* & $\mathrm{N}$ & & \\
\hline \multirow[t]{2}{*}{ XopAD } & XTALMG727_0614 & XTPLMG728_3670 & XTPLMG730_1368 & 91.65 & 0.0 \\
\hline & XTALMG727_1307 & $\mathrm{N}$ & $\mathrm{N}$ & & \\
\hline ХорАН & $\mathrm{N}$ & $\mathrm{N}$ & XTPLMG730_1645* & & \\
\hline \multirow[t]{2}{*}{ XopB } & XTALMG727_0958* & XTPLMG728_0265* & XTPLMG730_1037 & 83.91 & 0.0 \\
\hline & $N$ & $\mathrm{~N}$ & XTPLMG730_1038* & & \\
\hline XopC & XTALMG727_2735 & XTPLMG728_0929 & XTPLMG730_2930 & 93.06 & 0.0 \\
\hline XopE & $N$ & $\mathrm{~N}$ & XTPLMG730_2339* & & \\
\hline \multirow[t]{3}{*}{ XopF } & XTALMG727_0160 & XTPLMG728_3393* & XTPLMG730_0026* & 95.18 & 0.0 \\
\hline & XTALMG727_0243 & XTPLMG728_2858* & $N$ & 85.88 & 0.0 \\
\hline & XTALMG727_0242* & $\mathrm{N}$ & $N$ & & \\
\hline XopG & XTALMG727_1016 & XTPLMG728_2920 & XTPLMG730_2662 & 75.58 & $3 E-111$ \\
\hline $\mathrm{XopH}$ & XTALMG727_1259 & $\mathrm{N}$ & $N$ & & \\
\hline Xopl & XTALMG727_3409 & $\mathrm{N}$ & XTPLMG730_3626 & 89.28 & 0.0 \\
\hline \multirow[t]{2}{*}{ XopJ } & XTALMG727_3363 & $\mathrm{N}$ & $\mathrm{N}$ & & \\
\hline & XTALMG727_3364* & $\mathrm{N}$ & $N$ & & \\
\hline XopK & XTALMG727_1234* & XTPLMG728_3296* & XTPLMG730_2968* & 95.06 & 0.0 \\
\hline \multirow[t]{3}{*}{ XopL } & XTALMG727_3597* & XTPLMG728_2315* & XTPLMG730_2526* & 81.55 & 0.0 \\
\hline & XTALMG727_3852* & XTPLMG728_3529* & XTPLMG730_3754* & 58.94 & $1 E-176$ \\
\hline & N & $\mathrm{N}$ & XTPLMG730_3767* & & \\
\hline XopN & XTALMG727_1719 & XTPLMG728_0715 & XTPLMG730_2395 & 92.85 & 0.0 \\
\hline \multirow[t]{4}{*}{ XоpP } & XTALMG727_0476* & XTPLMG728_1678* & XTPLMG730_0352* & 90.97 & 0.0 \\
\hline & XTALMG727_1884* & XTPLMG728_2570* & XTPLMG730_3584* & 86.94 & 0.0 \\
\hline & N & XTPLMG728_3453 & XTPLMG730_0007 & 93.01 & $2 \mathrm{E}-125$ \\
\hline & $N$ & XTPLMG728_3824* & $\mathrm{N}$ & & \\
\hline XopQ & XTALMG727_3080* & XTPLMG728_1854* & XTPLMG730_2816* & 97.69 & 0.0 \\
\hline XopR & XTALMG727_2355 & XTPLMG728_1451 & XTPLMG730_1831 & 83.78 & $3 E-124$ \\
\hline XopV & XTALMG727_0112* & XTPLMG728_3243* & XTPLMG730_2612* & 90.94 & 0.0 \\
\hline \multirow[t]{2}{*}{ XopX } & XTALMG727_1509 & XTPLMG728_1839 & XTPLMG730_0225 & 85.66 & 0.0 \\
\hline & XTALMG727_2734 & XTPLMG728_0930 & XTPLMG730_2929 & 90.32 & 0.0 \\
\hline XopZ & XTALMG727_0656 & XTPLMG728_3741 & XTPLMG730_1408 & 97.52 & 0.0 \\
\hline XорAM & XTALMG727_2702* & XTPLMG728_2341* & XTPLMG730_3036* & 96.69 & 0.0 \\
\hline XopAF & $N$ & XTPLMG728_1151 & $N$ & & \\
\hline AvrXccA & $\mathrm{N}$ & XTPLMG728_0197 & XTPLMG730_0963 & 96.77 & 0.0 \\
\hline- & XTALMG727_0041* & XTPLMG728_0463* & XTPLMG730_1692* & 87.88 & $3 E-149$ \\
\hline- & XTALMG727_1653* & $\mathrm{N}$ & $N$ & & \\
\hline
\end{tabular}

\footnotetext{
${ }^{a}$ Assigned effector classes based on sequence homology to T3Es listed in the publication of White et al. [36] and publically accessible data [34] ${ }^{b}$ Identified effector proteins are listed by the corresponding locus tags, while $\mathrm{N}$ indicates, that no homologous effector protein could be identified. The presence of PIP-boxes is indicated by asterisks $\left(^{*}\right)$
} 
727, LMG 728, LMG 730) carried a hypersensitivity response and pathogenicity ( $h r p$ ) gene cluster homologous to the non-canonical type III secretion system recently published as a prevalent finding in the genome of Xanthomonas translucens pv. graminis strain Xtg29 [8]. However, in the genome of LMG 728 the neighboring genes $h r c C$ and $h r p X$ were more distantly located to the main part of the hrp gene cluster.

\section{Characterization of further virulence-related traits}

In addition to the type III secretion of effector proteins, a wide range of additional mechanisms contribute to bacterial virulence. In the early stages of pathogenesis, flagellar-mediated motility represents a prevalent mechanism for invasion of the host plant [39]. The presence of a flagellar gene cluster [40] was common for LMG 727, LMG 728 and LMG 730 and confirmed by the motility observed for these three strains (data not shown). Successful host colonization is further depending on type I and type II secretion systems which are involved in the translocation of virulence factors (i.e. toxins and degradative enzymes) and thus substantially contribute to bacterial virulence [41]. A T2SS encoding xps gene cluster [42] as well as the corresponding rax genes of the T1SS [43] were identified for the pathovar reference strains LMG 727, LMG 728 and LMG 730. Furthermore, in all three genomes homology to the chromosomal type IV secretion system gene cluster of $X$. axonopodis pv. citri [44] was observed; however, a corresponding virB7 homologue could not be identified in any of the strains.

Whereas all of the above mentioned gene clusters were found to be highly conserved among the three pathovar reference strains, we observed a significant difference for the $\mathrm{O}$-antigen encoding part of the lipopolysaccharide (LPS) gene cluster [45]. While the flanking genes of this region, i.e. etfA and metC are widely conserved among Xanthomonas spp. a highly divergent gene content has been reported for the interjacent region [46, 47]. Comparison of the corresponding region of LMG 727, LMG 728 and LMG 730 revealed 21, 18 and 19 genes, respectively. Among these, 16 to 17 were homologous across all three genomes. Differences in the number of homologous genes were due to nonsense mutations, which caused gene separation in two individual genes for LMG 727 and LMG 728.

Another inter-pathovar difference was found for the gum gene cluster, which encodes for xanthan biosynthesis [48]. This extracellular polysaccharide has recently been shown to be involved in biofilm formation and to promote epiphytic growth on host plants [49, 50]. Both, LMG 728 and LMG 730 possessed 11 gum genes as described recently for $X$. translucens pv. graminis Xtg29 [8]. Also the LMG 727 genome was found to largely encode the corresponding gene cluster; however, missense mutation of the stop codon in gumK resulted in a gene fusion with the neighboring upstream gene gumL. Analysis of deletion mutants of both genes in $X$. oryzae pv. oryzae revealed only minor effects on xanthan production and no reduced virulence for the gumL mutant, while the gumK mutant was characterized by both, a reduced xanthan production and impaired virulence on rice leaves [51]. However, considering the mucoid phenotype of LMG 727 (Fig. 1), production of the exopolysaccharide xanthan seemed not impaired by the observed nonstop mutation. Moreover, the rpf gene cluster, involved in the regulation of xanthan production and further virulencerelated features [52], was identified in the LMG 728 and LMG 730 genomes as well as for LMG 727.

Both, the LPS and xanthan biosynthesis gene clusters, revealed distinct characteristics of the pv. arrhenatheri reference strain. Along with these findings, we identified a nonribosomal peptide synthetase gene cluster consisting of 10 genes to be solely present in the LMG 727 genome.

\section{Conclusions}

Aiming to identify virulence factors putatively involved in host range specificity of forage grass pathogens, we sequenced three pathovar reference strains of the species Xanthomonas translucens. In a first step, we analyzed the strain-specific type III effector repertoires, which indicated clear inter-pathovar differences along with a subset of effector proteins highly conserved among all three strains. Accordingly, high conformity in gene content and sequence homology were identified for four secretion systems and the flagellar gene cluster, whereas all three genomes were found to be characterized by a divergent gene cluster of LPS biosynthesis when compared to each other. With regard to the deviating gene content of the gum gene cluster and the identified NRPS genes, the pv. arrhenatheri reference strain LMG 727 revealed further pathovar-specific characteristics. Altogether, these data sets represent a useful basis for the functional analysis of distinct genomic traits involved in host range adaptation of $X$. translucens pathovars and a valuable resource for future breeding strategies towards resistant forage grass cultivars.

\section{Acknowledgements \\ The authors would like to thank Anika Winkler for the assistance during genome sequencing and the Swiss National Science Foundation for funding of this project (138358). Also the bioinformatics support of the BMBF-funded project 'Bielefeld- Gießen Center for Microbial Bioinformatics - BiGi (Grant number 031A533)' within the German Network for Bioinformatics Infrastructure (de.NBI) as well as the assist- ance by Aurélien Bailly in taking the micrographs are gratefully acknowledged.}

\section{Authors' contributions}

LH was involved in the design of the study, prepared genomic DNA for sequencing, contributed to data analysis, interpreted the data and wrote the manuscript. DW conducted genome assembly and annotation, helped to interpret the data and contributed to drafting the manuscript. FJV and FW helped with the design of the study and critically revised the manuscript. RK was involved in conception and design, helped to interpret the data and contributed to writing the manuscript. All authors read and approved the final manuscript. 


\section{Competing interests}

The authors declare that they have no competing interests.

\section{Author details}

${ }^{1}$ Molecular Ecology, Institute for Sustainability Sciences, Agroscope, Zurich, Switzerland. ${ }^{2}$ Center for Biotechnology, Bielefeld University, Bielefeld, Germany.

\section{Received: 22 January 2016 Accepted: 3 August 2016}

Published online: 17 August 2016

\section{References}

1. Leyns F, De Cleene M, Swings JG, De Ley J. The host range of the genus Xanthomonas. Bot Rev. 1984;50:308-56.

2. Sletten A. Detection methods for Xanthomonas campestris pv. graminis on forage grasses. Bull OEPP/EPPO Bull. 1989;19:69-72.

3. Egli T, Goto M, Schmidt D. Bacterial wilt, a new forage grass disease. Phytopathol Z. 1975:82:111-21.

4. Egli T, Schmidt D. Pathogenic variation among the causal agents of bacterial wilt of forage grasses. Phytopathol Z. 1982;104:138-50.

5. Channon AG, Hissett R. The incidence of bacterial wilt caused by Xanthomonas campestris pv graminis in pasture grasses in the West of Scotland. Plant Pathol. 1984;33:113-21.

6. Leyns F, Van den Mooter M, Swings J, De Cleene M, De Ley J. Distribution of Xanthomonas campestris pv. graminis in fields of forage grasses in northern Belgium. Parasitica. 1981:37:131-3.

7. Vauterin L, Hoste B, Kersters K, Swings J. Reclassification of Xanthomonas. Int J Syst Bacteriol. 1995:45:472-89.

8. Wichmann F, Vorhölter F-J, Hersemann L, Widmer F, Blom J, Niehaus K, et al. The noncanonical type III secretion system of Xanthomonas translucens pv. graminis is essential for forage grass infection. Mol Plant Pathol. 2013;14:576-88.

9. Swings J, Vauterin L, Kersters K. The bacterium Xanthomonas. In: Swings J, Civerolo EL, editors. Xanthomonas. London: Chapman \& Hall; 1993. p. 121-56.

10. Van den Mooter M, Swings J. Numerical analysis of 295 phenotypic features of 266 Xanthomonas strains and related strains and an improved taxonomy of the genus. Int J Syst Bacteriol. 1990;40:348-69.

11. Leyns F, De Cleene M, Van Bogaert G, Van de Wiele A, De Ley J. Preliminary investigations about the mode of transmission and spread of Xanthomonas campestris pv. graminis on forage grasses. J Phytopathol. 1988;122:76-88.

12. Hayward AC. The hosts of Xanthomonas. In: Swings J, Civerolo EL, editors. Xanthomonas. London: Chapman \& Hall; 1993. p. 1-119.

13. Parkinson N, Cowie C, Heeney J, Stead D. Phylogenetic structure of Xanthomonas determined by comparison of gyrB sequences. Int J Syst Evol Microbiol. 2009;59:264-74.

14. Parkinson N, Aritua V, Heeney J, Cowie C, Bew J, Stead D. Phylogenetic analysis of Xanthomonas species by comparison of partial gyrase B gene sequences. Int J Syst Evol Microbiol. 2007;57:2881-7.

15. Field D, Garrity G, Gray T, Morrison N, Selengut J, Sterk P, et al. The minimum information about a genome sequence (MIGS) specification. Nat Biotechnol. 2008:26:541-7.

16. William S, Feil H, Copeland A. Bacterial genomic DNA isolation using CTAB. In: Protocols. Joint Genome Institute. 2012. http://jgi.doe.gov/ collaborate-with-jgi/pmo-overview/protocols-sample-preparationinformation/. Accessed 04 Feb 2014

17. Meyer F, Goesmann A, McHardy AC, Bartels D, Bekel T, Clausen J, et al. GenDB - an open source genome annotation system for prokaryote genomes. Nucleic Acids Res. 2003;31:2187-95.

18. Hyatt D, Chen G-L, LoCascio PF, Land ML, Larimer FW, Hauser LJ. Prodigal: prokaryotic gene recognition and translation initiation site identification. BMC Bioinformatics. 2010. doi:10.1186/1471-2105-11-119.

19. Lagesen $K$, Hallin P, Rødland EA, Stærfeldt HH, Rognes T, Ussery DW. RNAmmer: consistent and rapid annotation of ribosomal RNA genes. Nucleic Acids Res. 2007:35:3100-8.

20. Lowe TM, Eddy SR. tRNAscan-SE: a program for improved detection of transfer RNA genes in genomic sequence. Nucleic Acids Res. 1997;25:955-64.

21. Bairoch A, Boeckmann B, Ferro S, Gasteiger E. Swiss-Prot: juggling between evolution and stability. Brief Bioinform. 2004:5:39-55.

22. Kanehisa M, Goto S, Sato Y, Kawashima M, Furumichi M, Tanabe M. Data information, knowledge and principle: back to metabolism in KEGG. Nucleic Acids Res. 2014. doi:10.1093/nar/gkt1076.
23. Finn RD, Bateman A, Clements J, Coggill P, Eberhardt RY, Eddy SR, et al. Pfam: the protein families database. Nucleic Acids Res. 2014. doi:10.1093/nar/gkt1223.

24. Haft DH, Selengut JD, White $O$. The TIGRFAMs database of protein families. Nucleic Acids Res. 2003:31:371-3.

25. Mitchell A, Chang H-Y, Daugherty L, Fraser M, Hunter S, Lopez R, et al. The InterPro protein families database: the classification resource after 15 years. Nucleic Acids Res. 2015. doi:10.1093/nar/gku1243.

26. Bendtsen JD, Nielsen H, von Heijne G, Brunak S. Improved prediction of signal peptides: SignalP 3.0. J Mol Biol. 2004;340:783-95.

27. Krogh A, Larsson B, von Heijne G, Sonnhammer ELL. Predicting transmembrane protein topology with a hidden Markov model: application to complete genomes. J Mol Biol. 2001;305:567-80.

28. Tatusov RL, Fedorova ND, Jackson JD, Jacobs AR, Kiryutin B, Koonin EV, et al. The COG database: an updated version includes eukaryotes. BMC Bioinformatics. 2003. doi:10.1186/1471-2105-4-41.

29. Harris MA, Clark J, Ireland A, Lomax J, Ashburner M, Foulger R, et al. The gene ontology (GO) database and informatics resource. Nucleic Acids Res. 2004. doi:10.1093/nar/gkh036.

30. Bland C, Ramsey TL, Sabree F, Lowe M, Brown K, Kyrpides NC, et al. CRISPR recognition tool (CRT): a tool for automatic detection of clustered regularly interspaced palindromic repeats. BMC Bioinformatics. 2007. doi:10.1186/ 1471-2105-8-209.

31. Kay S, Bonas U. How Xanthomonas type III effectors manipulate the host plant. Curr Opin Microbiol. 2009;12:37-43.

32. Gu KY, Yang B, Tian DS, Wu LF, Wang DJ, Sreekala C, et al. R gene expression induced by a type-III effector triggers disease resistance in rice. Nature. 2005:435:1122-5.

33. Hajri A, Brin C, Hunault G, Lardeux F, Lemaire C, Manceau C, et al. A "repertoire for repertoire" hypothesis: repertoires of type three effectors are candidate determinants of host specificity in Xanthomonas. PLoS ONE. 2009. doi:10.1371/journal.pone.0006632

34. Koebnik R. Type III effectors. In: The Xanthomonas Resource. 2014. http:// xanthomonas.org/t3e.html. Accessed 15 May 2015

35. Altschul SF, Gish W, Miller W, Myers EW, Lipman DJ. Basic local alignment search tool. J Mol Biol. 1990;215:403-10.

36. White FF, Potnis $\mathrm{N}$, Jones JB, Koebnik R. The type III effectors of Xanthomonas. Mol Plant Pathol. 2009;10:749-66.

37. Boch J, Bonas U. Xanthomonas AvrBs3 family-type III effectors: discovery and function. Annu Rev Phytopathol. 2010;48:419-36.

38. Galán JE, Collmer A. Type III secretion machines: bacterial devices for protein delivery into host cells. Science. 1999;284:1322-8.

39. Moens S, Vanderleyden J. Functions of bacterial flagella. Crit Rev Microbiol. 1996;22:67-100

40. Thieme F, Koebnik R, Bekel T, Berger C, Boch J, Buttner D, et al. Insights into genome plasticity and pathogenicity of the plant pathogenic bacterium Xanthomonas campestris pv. vesicatoria revealed by the complete genome sequence. J Bacteriol. 2005;187:7254-66.

41. Gerlach RG, Hensel M. Protein secretion systems and adhesins: the molecular armory of Gram-negative pathogens. IJMM. 2007;297:401-15.

42. Szczesny R, Jordan M, Schramm C, Schulz S, Cogez V, Bonas U, et al. Functional characterization of the Xcs and Xps type II secretion systems from the plant pathogenic bacterium Xanthomonas campestris pv vesicatoria. New Phytol. 2010:187:983-1002.

43. da Silva FG, Shen YW, Dardick C, Burdman S, Yadav RC, de Leon AL, et al. Bacterial genes involved in type I secretion and sulfation are required to elicit the rice Xa21-mediated innate immune response. Mol Plant Microbe Interact. 2004;17:593-601.

44. Alegria MC, Souza DP, Andrade MO, Docena C, Khater L, Ramos CHl, et al. Identification of new protein-protein interactions involving the products of the chromosome- and plasmid-encoded type IV secretion loci of the phytopathogen Xanthomonas axonopodis pv. citri. J Bacteriol. 2005;187:2315-25.

45. Vorhölter FJ, Niehaus K, Pühler A. Lipopolysaccharide biosynthesis in Xanthomonas campestris pv. campestris: a cluster of 15 genes is involved in the biosynthesis of the LPS O-antigen and the LPS core. Mol Genet Genomics. 2001;266:79-95.

46. Lu H, Patil P, Van Sluys M-A, White FF, Ryan RP, Dow JM, et al. Acquisition and evolution of plant pathogenesis-associated gene clusters and candidate determinants of tissue-specificity in Xanthomonas. PLoS ONE. 2008. doi:10. 1371/journal.pone.0003828

47. Patil PB, Sonti RV Variation suggestive of horizontal gene transfer at a lipopolysaccharide (Ips) biosynthetic locus in Xanthomonas oryzae pv. 
oryzae, the bacterial leaf blight pathogen of rice. BMC Microbiol. 2004. doi: 10.1186/1471-2180-4-40.

48. Katzen F, Becker A, Zorreguieta A, Puehler A, lelpi L. Promoter analysis of the Xanthomonas campestris pv. campestris gum operon directing biosynthesis of the xanthan polysaccharide. J Bacteriol. 1996;178:4313-8.

49. Rigano LA, Siciliano F, Enrique R, Sendin L, Filippone P, Torres PS, et al. Biofilm formation, epiphytic fitness, and canker development in Xanthomonas axonopodis pv. citri. Mol Plant Microbe Interact. 2007;20:1222-30.

50. Kemp BP, Horne J, Bryant A, Cooper RM. Xanthomonas axonopodis pv. manihotis gumD gene is essential, for EPS production and pathogenicity and enhances epiphytic survival on cassava (Manihot esculenta). Physiol Mol Plant Pathol. 2004;64:209-18.

51. Kim S-Y, Kim J-G, Lee B-M, Cho J-Y. Mutational analysis of the gum gene cluster required for xanthan biosynthesis in Xanthomonas oryzae pv oryzae. Biotechnol Lett. 2009:31:265-70.

52. Dow JM, Crossman L, Findlay K, He YQ, Feng JX, Tang JL. Biofilm dispersal in Xanthomonas campestris is controlled by cell-cell signaling and is required for full virulence to plants. Proc Natl Acad Sci U S A. 2003;100: 10995-1000

53. Woese CR, Kandler O, Wheelis ML. Towards a natural system of organisms: proposal for the domains Archaea, Bacteria, and Eucarya. Proc Natl Acad Sci U S A. 1990;87:4576-9.

54. Garrity GM, Bell JA, Lilburn T. Phylum XIV. Proteobacteria phyl. nov. In: Garrity GM, Brenner DJ, Krieg NR, Staley JT, editors. Bergey's manual of systematic bacteriology. Volume 2, Part B. New York: Springer; 2005. p. 1.

55. Garrity GM, Bell JA, Class III LT. Gammaproteobacteria class. nov. In: Garrity GM, Brenner DJ, Krieg NR, Staley JT, editors. Bergey's manual of systematic bacteriology. Volume 2, Part B. New York: Springer; 2005. p. 1.

56. Validation of publication of new names and new combinations previously effectively published outside the IJSEM. List no. 106. Int J Syst Evol Microbiol. 2005;55:2235-8.

57. Saddler GS, Bradbury JF. Order III. Xanthomonadales ord. nov. In: Garrity GM, Brenner DJ, Krieg NR, Staley JT, editors. Bergey's manual of systematic bacteriology. Volume 2, Part B. New York: Springer; 2005. p. 63.

58. Saddler GS, Bradbury JF. Family I. Xanthomonadaceae fam. nov. In: Garrity GM, Brenner DJ, Krieg NR, Staley JT, editors. Bergey's manual of systematic bacteriology. Volume 2, Part B. New York: Springer; 2005. p. 63.

59. Dowson DW. On the systematic position and generic names of the Gram negative bacterial plant pathogens. Zentralblatt für Bakteriologie, Parasitenkunde und Infektionskrankheiten Abteilung II. 1939;100:177-93.

60. Skerman VBD, McGowan V, Sneath PHA. Approved list of bacterial names. Int J Syst Bacteriol. 1980;30:225-420

61. Bull CT, De Boer SH, Denny TP, Firrao G, Fischer-Le Saux M, Saddler GS, et al. Comprehensive list of names of plant pathogenic bacteria, 1980-2007. J Plant Pathol. 2010;92:551-92.

62. Ashburner M, Ball CA, Blake JA, Botstein D, Butler H, Cherry JM, et al. Gene ontology: tool for the unification of biology. Nat Genet. 2000;25:25-9.

63. Tamura K, Stecher G, Peterson D, Filipski A, Kumar S. MEGA6: molecular evolutionary genetics analysis version 6.0. Mol Biol Evol. 2013;30:2725-9.

\section{Submit your next manuscript to BioMed Central and we will help you at every step:}

- We accept pre-submission inquiries

- Our selector tool helps you to find the most relevant journal

- We provide round the clock customer support

- Convenient online submission

- Thorough peer review

- Inclusion in PubMed and all major indexing services

- Maximum visibility for your research

Submit your manuscript at www.biomedcentral.com/submit

C Biomed Central 